\title{
Exceptional soft-tissue preservation in boring ctenostome bryozoans and associated "fungal" borings from the Early Devonian of Podolia, Ukraine
}

Ewa Olempska

Acta Palaeontologica Polonica 57 (4), 2012: 925-940 doi: http://dx.doi.org/10.4202/app.2011.0200

Colonies of boring ctenostome bryozoans and microborings of "fungi" that occur in the Early Devonian (Lochkovian, 416 Ma) of Podolia, western Ukraine, have soft-tissue preserved by phosphatization. These comprise exceptional three-dimensional body walls of feeding zooids with probable parietal muscles inserted on the cystid wall, and setigerous collars twisted within the vestibulum. The presence of collars in this Early Devonian ctenostomes proves the existence of this feature for more than $416 \mathrm{Ma}$ of ctenostome evolution. Phosphatized remains of the zooid walls are interpreted as relicts of the originally chitinous cystid walls. This is the first record of soft-tissue fossilization in a boring bryozoan. The presence of cavities (specialized heterozooids), empty or filled with laminated calcium phosphate, is also documented in bryozoans for the first time. These cavities are interpreted as "store-rooms" in which the bryozoans accumulated nutrients. The new taxon, Podoliapora doroshevi gen. et sp. nov. is described. In additional, phosphatised fungi-like endoliths co-occur with bryozoans.

Key words: Bryozoa, Fungi, phosphatization, soft-tissue, demineralization, Devonian, Podolia, Ukraine.

Ewa Olempska [olempska@twarda.pan.pl], Institute of Paleobiology, Polish Academy of Sciences, Twarda 51/55, PL 00-818 Warsaw, Poland.

This is an open-access article distributed under the terms of the Creative Commons Attribution License (for details please see creativecommons.org), which permits unrestricted use, distribution, and reproduction in any medium, provided the original author and source are credited. 
